\title{
Nutritional Studies on the Use of Garlic, Cinnamon and Peppermint in Sheep Nutrition and Their Impact on Gas Production and Digestibility
}

\author{
Saad, D. E.; A. A. Osman ${ }^{*}$ and S. A. Soliman \\ Department of Animal Production, Faculty of Agriculture, Suez Canal University, Egypt
}

Received: $1 / 10 / 2016$

\begin{abstract}
The present study was carried out at the Animal Research Farm, Faculty of Agriculture, Suez Canal University, Ismailia, Egypt: in vitro assay. The treatments were: 1- control: concentrate feed mixture (CFM) + Rice straw (RS) (2:1) without additives, 2- control diet + garlic powder $0.5 \%$, 3- control diet + garlic powder $1 \%$, 4- control diet + garlic powder $1.5 \%, 5$ - control diet + garlic powder $2 \%$, 6- control diet + garlic powder $2.5 \%$, 7- control diet + cinnamon powder $0.5 \%, 8$ - control diet + cinnamon powder $1 \%$, 9- control diet + cinnamon powder $1.5 \%$, 10 - control diet + cinnamon powder $2 \%$, 11 - control diet + cinnamon powder $2.5 \%$, 12 - control diet + peppermint powder $0.5 \%$, 13- control diet + peppermint powder $1 \%, 14$ - control diet + peppermint powder $1.5 \%$. 15 - control diet + peppermint powder $2 \%$ and 16 - control diet + peppermint powder $2.5 \%$. Ten digestibility trials were conducted on sheep to evaluate the experimental rations as the following treatments: Ration 1- (Control): (CFM) and wheat straw (WS) (ratio 2:1) without any additives, Ration 2 - CFM and WS $+1.5 \%$ garlic powder, Ration $3-$ CFM and $\mathrm{WS}+2 \%$ garlic powder, Ration 4- CFM and WS $+2.5 \%$ garlic powder, Ration 5- CFM and WS $+1.5 \%$ cinnamon powder, Ration 6- CFM and $\mathrm{WS}+2 \%$ cinnamon powder, Ration 7 - CFM and WS $+2.5 \%$ cinnamon powder, Ration 8 - CFM and WS $+1.5 \%$ peppermint powder, Ration 9- CFM and WS $+2 \%$ peppermint powder and Ration 10 CFM and WS $+2.5 \%$ peppermint powder. Most treatments significantly increased in vitro dry matter disappearance (IVDMD) and in vitro organic matter disappearance (IVOMD) compared with control. $2 \%$ garlic and $2.5 \%$ cinnamon significantly decreased gas production after $24 \mathrm{hr}$. The digestibility trials showed that the three plants by $2.5 \%$ has given the best results and dry matter digestibility was significantly increased except garlic and significantly increased organic matter, crude protein, crude fiber, nitrogen free extracts and nutritive values as TDN and DCP. It could be concluded that the three plants as a nature additives in ruminant diet decreased gas production and improved animal digestibility.
\end{abstract}

Keywords: Garlic, cinnamon, peppermint, gas production, in vitro and digestibility.

\section{INTRODUCTION}

Global warming, which results in an increase in the earth's atmospheric temperature, is purported to cause climate change leading to the exacerbation of extreme weather events and the frequency of their occurrence. Principal greenhouse gases are carbon dioxide ( $\mathrm{CO} 2)$, methane ( $\mathrm{CH} 4)$, nitrous oxide (N2O). These gases accumulate in the atmosphere and increasing with time. Methane is an important greenhouse gas followed carbon dioxide in its contribution to global warming (IPCC, 2007). Methane contribution is 23 times more potent than carbon dioxide. It was estimated that livestock produced $18 \%$ of all global greenhouse gas emission, greater than all forms of transportation (Takahashi et al., 2005). Methane is an important part in gas emitted in the rumen, and methane is estimated from ruminants about $15 \%$ of total atmospheric methane emissions.

Moreover, methane emission represents a loss of carbon sources from the rumen, leading to an unproductive use of dietary energy, and results in the substantial loss of up to $12 \%$ of the dietary energy intake (Johnson and Johnson, 1995). Therefore, decreasing of methane emission from ruminant livestock urgently needed to decrease the environmental impact of ruminant livestock and increasing performance of ruminants. Mitsumori and Sun (2008) suggested that the reduction of methane emissions from the rumen could be include controlling in animal feed components, biological control of rumen fermentation and using feed additives.
Feed additives from different plant sources were using to improve utilization of dietary nutrients. While this trend is greatly increasing, it could pose a health threat giving the adverse effects of some chemical additives on human health. This highlights the using natural feed additives as to minimize or even eliminate these adverse effects. Several natural feed additives have been used for their therapeutic and prophylactic traits. In addition, medicinal herbs are contains aromatic substances and essential oils.

Recently, many plant extracts have been studied for their antimicrobial activity and ability to modify gut function in both ruminant and non-ruminant and could be promising in mitigating methane emission from ruminants owing to their direct effects on methanogenesis and fermentation processes (Kamra et al, 2006; Cobellis et al., 2016).

\section{MATRIALES and METHODS}

In vitro dry matter disappearance (IVDMD) and in vitro organic matter disappearance (IVOMD) were carried out for evaluation the mixtures of concentrate feed mixture $(\mathrm{CFM})+$ rice straw $(\mathrm{RS})(2: 1)$ without any additives (control) and same mixture with additives of some different percentages of garlic, cinnamon or peppermint powder as follows: 1- Control: Concentrate feed mixture (CFM) + Rice straw (RS) (2:1) without additives, $2-\mathrm{CFM}+\mathrm{RS}(2: 1)+$ garlic powder $0.5 \%$, 3$\mathrm{CFM}+\mathrm{RS}(2: 1)+$ garlic powder $1 \%, 4-\mathrm{CFM}+\mathrm{RS}$ $(2: 1)+$ garlic powder $1.5 \%, 5-\mathrm{CFM}+\mathrm{RS}(2: 1)+$ garlic 
powder 2\%, 6- CFM + RS (2:1) + garlic powder $2.5 \%, 7-\mathrm{CFM}+\mathrm{RS}(2: 1)+$ cinnamon powder $0.5 \%$, 8$\mathrm{CFM}+\mathrm{RS}(2: 1)+$ cinnamon powder $1 \%, 9-\mathrm{CFM}+\mathrm{RS}$ $(2: 1)+$ cinnamon powder $1.5 \%, 10-\mathrm{CFM}+\mathrm{RS}(2: 1)+$ cinnamon powder $2 \%, 11-\mathrm{CFM}+\mathrm{RS}(2: 1)+$ cinnamon powder $2.5 \%$, 12- CFM + RS $(2: 1)+$ peppermint powder $0.5 \%$, 13- CFM + RS $(2: 1)+$ peppermint powder $1 \%, 14-\mathrm{CFM}+\mathrm{RS}(2: 1)+$ peppermint powder $1.5 \%$. $15-$ CFM + RS $(2: 1)+$ peppermint powder $2 \%$ and $16-\mathrm{CFM}+\mathrm{RS}(2: 1)+$ peppermint powder $2.5 \%$.

McDougall's Buffer prepared according to McDougall (1948). Weight $0.18 \mathrm{~g}$ of feed mixture with or without additives in the bottles. The rumen liquor was collected from sheep ( 3 rams) after 2 hours from morning feeding by stomach tube then filtered through three layers of gauze. The McDougall Buffer was mixed with rumen fluid at (1:1).The mixture saturation by carbon dioxide gas $\left(\mathrm{CO}_{2}\right)$ at $39^{\circ} \mathrm{C}$.

Blank preparation: Add $18 \mathrm{ml}$ of inoculum (mixture of rumen fluid and McDougall Buffer) in three digestion bottles and incubation with treatments in the water bath.

In vitro incubation: Add $18 \mathrm{ml}$ of inoculum to digestion bottles and incubation in the water bath at $39^{\circ} \mathrm{C}$ for $48 \mathrm{hr}$., then centrifuged and separation the liquid and consequently add pepsin solution $4 \%$ on the residual deposit for $24 \mathrm{hr}$, then centrifuged and separation the liquid. The bottles put in a drying oven at $65^{\circ} \mathrm{C}$ for $24 \mathrm{hr}$., then dried at $105^{\circ} \mathrm{C}$ for $3 \mathrm{hr}$. then weight for determined residual dry matter (DM). Samples put in burn oven at $600^{\circ} \mathrm{C}$ for $2 \mathrm{hr}$. to determined residual organic matter (OM). The (IVDMD) and (IVOMD) determined according to Tilley and Terry (1963).

Gas Production: The fermentation is carried out in syringes for determined gas production. Weight $0.18 \mathrm{~g}$ of feed mixture and $18 \mathrm{ml}$ of inoculum will adding in syringe, and incubated at the water bath at $39^{\circ} \mathrm{C}$ for 48 $\mathrm{hr}$. The gas production was measured at 24 and $48 \mathrm{hr}$.

Digestibility trials: The digestibility was evaluated using mature local rams aged about 2 years, average weight were $40 \mathrm{~kg}$. The rams were divided into 10 groups ( 3 rams in each group). The animals in groups were fed the rations as follows: Ration1- (Control): (CFM) and wheat straw (WS) (ratio 2:1) without any Additives, Ration 2- CFM and WS $+1.5 \%$ garlic powder, Ration 3- CFM and WS $+2 \%$ garlic powder, Ration 4- CFM and WS $+2.5 \%$ garlic powder, Ration 5- CFM and WS $+1.5 \%$ cinnamon powder, Ration 6CFM and WS $+2 \%$ cinnamon powder, Ration 7- CFM and WS $+2.5 \%$ cinnamon powder, Ration 8- CFM and WS $+1.5 \%$ peppermint powder, Ration 9- CFM and WS $+2 \%$ peppermint powder and Ration 10 CFM and $\mathrm{WS}+2.5 \%$ peppermint powder.

The digestibility was carried out by acid insoluble ash (AIA) as a natural marker according to Van Keulen and Young (1977). Chemical composition of representative samples was determined according to AOAC (1985) procedures.
Statistical analysis: All data were subjected to analysis was performed using the General linear Models procedure. Mean differences were compared using Duncan' multiple range test (Duncan, 1955). Data were analyzed using SPSS prog. The mathematical model as the follows:

$$
Y i j=\mu+T i+e i j
$$

where: $\mathrm{Yij}=$ Individual observation, $\mu=$ The overall mean for the trial under consideration, $\mathrm{Ti}=$ the effect of the ith treatment and eij $=$ Random residual error.

\section{RESULTS AND DISCUSSION}

\section{Chemical Composition:}

The data in Table (1) explained that the OM content of Peppermint was lower than garlic and cinnamon while the OM content in garlic and cinnamon were nearly similar. The $\mathrm{CP} \%$ was lower and $\mathrm{CF} \%$ was higher in cinnamon than garlic and peppermint. The chemical composition of calculated rations explained that the chemical composition of all treatments were similar except garlic and peppermint were slightly higher in $\mathrm{CP} \%$ than control and cinnamon treatment due to the high percent of CP in garlic and peppermint.

The values of IVDMD and IVOMD of highest level of additives $(2.5 \%)$ were higher $(\mathrm{P}<0.05)$ than control as shown in Table (2). These results agreed with those obtained by Kongmun et al. (2010) who showed that garlic powder supplementation $(16 \mathrm{mg} / 200 \mathrm{mg}$ DM) significantly increased in vitro true digestibility than control. The differences among all percentages of garlic additive except $2.5 \%$ and control were not significant.

These results agreed with those obtained by AlHadeethi et al. (2016) who found that the levels of garlic at $10,20 \mathrm{~g} / \mathrm{kg}$ DM don't significantly effect on in vitro DM digestibility. The differences among levels of $0.5,1.0$ and $2.0 \%$ of cinnamon and control were not significant. These results in harmony with Benchaar et al. (2007), who noticed that essential oil of cinnamon or cinnamaldehyde did not affect on IVDMD. The differences among levels $0.5,1.0$ and $2.0 \%$ of peppermint and control were not significant. These results agree with Patra and Yu (2012), who found that peppermint additive don't affect on apparent degradability of DM, true DM and NDF in in vitro. On contrary, some studies explained that some nature additives decreased in vitro digestibility (Kongmun et al., 2010) with garlic powder, Cobellis et al. (2016) with cinnamon bark essential oils and Sallam et al. (2011) with mentha essential oil.

\section{Gas Production}

Tables (3) shows data of gas production after 24 and $48 \mathrm{hr}$.gas production decreased in all additives (garlic, cinnamon and peppermint) than control except in garlic at levels 1 and $1.5 \%$ at 24 and $48 \mathrm{hr}$. of incubation and cinnamon at level $1 \%$ at $48 \mathrm{hr}$. of incubation. All levels of peppermint decreased gas production. 
Table (1): Chemical composition of ingredients and calculated rations with or without natural additives

\begin{tabular}{|c|c|c|c|c|c|c|c|}
\hline \multirow{2}{*}{ Items } & & \multicolumn{6}{|c|}{ Chemical Composition (on DM basis) } \\
\hline & & OM & $\mathbf{C P}$ & $\mathbf{C F}$ & E.E & NFE & Ash \\
\hline \multicolumn{2}{|l|}{ CFM* } & 95.18 & 18.97 & 4.02 & 4.28 & 67.91 & 4.82 \\
\hline \multicolumn{2}{|l|}{ Wheat straw } & 88.02 & 3.25 & 39.71 & 1.61 & 43.46 & 11.98 \\
\hline \multicolumn{2}{|l|}{ Rice straw } & 84.14 & 5.37 & 37.42 & 4.47 & 36.87 & 15.86 \\
\hline \multicolumn{2}{|l|}{ Garlic } & 94.97 & 18.98 & 2.00 & 1.15 & 72.84 & 5.03 \\
\hline \multicolumn{2}{|l|}{ Cinnamon } & 94.75 & 7.15 & 25.26 & 5.95 & 56.39 & 5.25 \\
\hline \multicolumn{2}{|l|}{ Peppermint } & 72.94 & 23.72 & 4.69 & 5.358 & 39.17 & 27.06 \\
\hline \multirow{2}{*}{\multicolumn{2}{|c|}{ Natural additives, \% }} & \multicolumn{6}{|c|}{ Chemical composition of calculated rations (on DM basis) } \\
\hline & & OM & $\mathbf{C P}$ & $\mathbf{C F}$ & E.E & NFE & Ash \\
\hline Control & 0 & 92.86 & 13.59 & 15.75 & 3.36 & 60.16 & 7.14 \\
\hline Garlic & 1.5 & 92.90 & 13.67 & 15.55 & 3.32 & 60.36 & 7.10 \\
\hline Cinnamon & 1.5 & 92.11 & 13.49 & 15.90 & 3.40 & 59.32 & 7.11 \\
\hline Peppermint & 1.5 & 92.57 & 13.74 & 15.59 & 3.39 & 59.85 & 7.44 \\
\hline Garlic & 2.0 & 92.91 & 13.70 & 15.48 & 3.31 & 60.42 & 7.09 \\
\hline Cinnamon & 2.0 & 92.90 & 13.46 & 15.94 & 3.41 & 60.09 & 7.10 \\
\hline Peppermint & 2.0 & 92.47 & 13.80 & 15.53 & 3.40 & 59.74 & 7.53 \\
\hline Garlic & 2.5 & 92.92 & 13.73 & 15.41 & 3.30 & 60.48 & 7.08 \\
\hline Cinnamon & 2.5 & 92.91 & 13.43 & 16.00 & 3.42 & 60.06 & 7.09 \\
\hline Peppermint & 2.5 & 92.37 & 13.84 & 15.48 & 3.41 & 59.64 & 7.63 \\
\hline
\end{tabular}

OM: Organic matter. CP: Crude protein. CF: Crude fiber. E.E: Ether extract. NFE: Nitrogen free extract.

Table (2): Effect of different additives with different levels on IVDMD and IVOMD

\begin{tabular}{|c|c|c|c|}
\hline \multirow{2}{*}{ Natural additives } & Garlic & Cinnamon & Peppermint \\
\hline & \multicolumn{3}{|c|}{ In vitro dry matter disappearance (IVDMD) } \\
\hline Control (0\%) & $57.13^{\mathrm{b}} \pm 0.34$ & $57.13^{b c} \pm 0.34$ & $57.13^{c} \pm 0.34$ \\
\hline $0.5 \%$ & $58.67^{\mathrm{abA}} \pm 1.27$ & $54.93^{\mathrm{cB}} \pm 0.56$ & $59.71^{\mathrm{bcA}} \pm 0.21$ \\
\hline $1.0 \%$ & $59.08^{\mathrm{ab}} \pm 2.77$ & $58.33^{b c} \pm 0.37$ & $57.37^{\mathrm{c}} \pm 1.57$ \\
\hline $1.5 \%$ & $63.90^{\mathrm{ab}} \pm 2.06$ & $60.77^{\mathrm{ab}} \pm 2.39$ & $61.33^{\mathrm{ab}} \pm 0.44$ \\
\hline $2.0 \%$ & $63.79^{\mathrm{ab}} \pm 3.28$ & $56.69^{b c} \pm 2.82$ & $59.79^{\mathrm{bc}} \pm 2.11$ \\
\hline \multirow[t]{2}{*}{$2.5 \%$} & $65.62^{\mathrm{a}} \pm 1.11$ & $64.15^{\mathrm{a}} \pm 1.72$ & $64.30^{\mathrm{a}} \pm 0.72$ \\
\hline & \multicolumn{3}{|c|}{ In vitro organic matter disappearance (IVOMD) } \\
\hline Control (0\%) & $59.17^{\mathrm{b}} \pm 0.35$ & $59.17^{\mathrm{bc}} \pm 0.35$ & $59.17^{\mathrm{c}} \pm 0.35$ \\
\hline $0.5 \%$ & $60.68^{\mathrm{Aab}} \pm 2.01$ & $55.27^{\mathrm{Bc}} \pm 0.60$ & $60.16^{\mathrm{Abc}} \pm 0.31$ \\
\hline $1.0 \%$ & $60.06^{\mathrm{b}} \pm 2.75$ & $59.31^{\mathrm{bc}} \pm .45$ & $58.64^{\mathrm{c}} \pm 1.14$ \\
\hline $1.5 \%$ & $65.42^{\mathrm{ab}} \pm 2.08$ & $62.69^{\mathrm{b}} \pm 2.41$ & $63.01^{\mathrm{ab}} \pm 0.68$ \\
\hline $2.0 \%$ & $65.44^{\mathrm{ab}} \pm 3.15$ & $58.62^{\mathrm{bc}} \pm 2.75$ & $61.67^{b c} \pm 2.11$ \\
\hline $2.5 \%$ & $67.84^{\mathrm{a}} \pm 1.68$ & $67.73^{\mathrm{a}} \pm 1.19$ & $66.42^{\mathrm{a}} \pm 0.99$ \\
\hline
\end{tabular}

Control: Concentrate feed mixture and rice straw (2:1) without Additives.

${ }_{\mathrm{AB}}$ means in the same row with different superscripts differ significantly $(\mathrm{P}<0.05)$

abc means in the same column with different superscripts differ significantly $(\mathrm{P}<0.05)$.

IVDMD: in vitro dry matter disappearance

IVOMD: in vitro organic matter disappearance 
These results agree with Patra and Yu (2012) and Ozkan et al. (2015) in peppermint. On the other hand, Al-Hadeethi et al. (2016) showed that the garlic extract don't significantly effect on gas and methane production at different levels in in vitro $(24 \mathrm{hr})$. In this connection, Macheboeuf et al. (2008) showed that low doses of cinnamaldehyde not affected on $\mathrm{CH}_{4}$ in in vitro, while medium doses slightly decreased $\mathrm{CH}_{4}$ production and the high doses of cinnamaldehyde decreased production of $\mathrm{CH}_{4}$ by $19 \%$.
Peppermint and cinnamon decreased $(\mathrm{P}<0.05)$ gas production than garlic at Levels 0.5, 1.5, 2.0 and 2.5\% at $48 \mathrm{hr}$. Cinnamon at level $1.5 \%$ significantly $(\mathrm{P}<0.05)$ decreased gas production than garlic and peppermint. The gas production in peppermint and cinnamon at level $1 \%$ was lower $(\mathrm{P}<0.05)$ than garlic. The peppermint at level $1 \%$ was significantly $(\mathrm{P}<0.05)$ lower than garlic and cinnamon at $48 \mathrm{hr}$. The best level of garlic and peppermint was at $0.5 \%$ and the best level of cinnamon was at $2.5 \%$.

Table (3): Effect of different additives with different levels on gas production (ml/gm DM) after incubation for 24 and $48 \mathrm{hr}$

\begin{tabular}{|c|c|c|c|}
\hline \multirow{2}{*}{ Items } & \multicolumn{3}{|c|}{24 hrs } \\
\hline & Garlic & Cinnamon & Peppermint \\
\hline Control (0\%) & $131.54 \pm 5.61^{\mathrm{a}}$ & $131.54 \pm 5.61^{\mathrm{a}}$ & $131.54 \pm 5.61^{\mathrm{a}}$ \\
\hline $0.5 \%$ & $124.15 \pm 4.89^{\mathrm{a}}$ & $111.2 \pm 3.16^{\mathrm{bc}}$ & $109.30 \pm 6.67^{b}$ \\
\hline $1 \%$ & $139.00 \pm 6.39^{\mathrm{Aa}}$ & $102.86 \pm 1.55^{\mathrm{Bc}}$ & $108.42 \pm 1.55^{\mathrm{Bb}}$ \\
\hline $1.5 \%$ & $142.66 \pm 4.89^{\mathrm{Aa}}$ & $104.69 \pm 2.44^{\mathrm{Cc}}$ & $115.81 \pm 0.88^{\mathrm{Bb}}$ \\
\hline $2.0 \%$ & $95.91 \pm 7.17^{\mathrm{Bb}}$ & $115.81 \pm 3.33^{\mathrm{Ab}}$ & $107.47 \pm 3.66^{\mathrm{ABb}}$ \\
\hline \multirow[t]{2}{*}{$2.5 \%$} & $127.88 \pm 3.16^{\mathrm{Aa}}$ & $91.74 \pm 1.55^{\mathrm{Cd}}$ & $111.2 \pm 5.56^{\mathrm{Bb}}$ \\
\hline & \multicolumn{3}{|c|}{$48 \mathrm{hrs}$} \\
\hline Control (0\%) & $155.68 \pm 7.78^{\mathrm{ab}}$ & $155.68 \pm 7.78^{b}$ & $155.68 \pm 7.78^{\mathrm{a}}$ \\
\hline $0.5 \%$ & $140.83 \pm 3.33^{\mathrm{Ab}}$ & $125.1 \pm 4.22^{\mathrm{Bc}}$ & $115.81 \pm 5.11^{\mathrm{Bb}}$ \\
\hline $1 \%$ & $158.90 \pm 7.78^{\mathrm{Aa}}$ & $176.02 \pm 1.83^{\mathrm{Aa}}$ & $116.76 \pm 6.39^{\mathrm{Bb}}$ \\
\hline $1.5 \%$ & $158.73 \pm 3.66^{\mathrm{Aa}}$ & $123.20 \pm 2.44^{\mathrm{Bc}}$ & $131.54 \pm 1.83^{\mathrm{Bb}}$ \\
\hline $2.0 \%$ & $145.95 \pm 2.39^{\mathrm{Aab}}$ & $132.49 \pm 2.44^{\mathrm{ABc}}$ & $118.59 \pm 7.39^{\mathrm{Bb}}$ \\
\hline $2.5 \%$ & $142.66 \pm 1.83^{\mathrm{Aab}}$ & $108.42 \pm 1.55^{\mathrm{Cd}}$ & $119.54 \pm 1.55^{\mathrm{Bb}}$ \\
\hline
\end{tabular}

Control: Concentrate feed mixture and rice straw (2:1) without Additives.

${ }_{\mathrm{AB}}$ means in the same row with different superscripts differ significantly $(\mathrm{P}<0.05)$

abcd means in the same column with different superscripts differ significantly $(\mathrm{P}<0.05)$.

\section{Digestion coefficients of nutrients:}

The digestion coefficients of nutrients are presented in Table (4). The DM digestibility of the diet with different levels of garlic was slightly increased than control but the differences were not significant. These results agreed with those of Benchaar and Greathead (2011) and Khalesizadeh et al. (2011). The three levels of cinnamon $(1.5,2.0$ and $2.5 \%)$ were increased $(\mathrm{P}<0.05) \mathrm{DM}$ digestibility than control but there are no significant differences between them. The DM digestibility at levels $2 \%$ and $2.5 \%$ of peppermint were higher $(\mathrm{P}<0.05)$ than control. These results agreed with those of Ando et al. (2003). On the other side, the differences among three additives were not significant.

The OM digestibility of control was lower $(\mathrm{P}<$ 0.05) than different levels of garlic, cinnamon or peppermint additives. However, the best level of garlic, cinnamon and peppermint was $2.5 \%$.

The CP and CF digestibility of control was lower $(\mathrm{P}<0.05)$ than all additives. The E.E digestibility of control was higher $(\mathrm{P}<0.05)$ than level $1.5 \%$ of all additives and lowers $(\mathrm{P}<0.05)$ than levels $2.5 \%$ of garlic and cinnamon and insignificantly lower than peppermint. These results inagreement with Hosoda et al. (2005) with peppermint. However, the best levels of garlic and peppermint were $2.5 \%$ and cinnamon was $2 \%$.

The NFE digestibility of control was lower $(\mathrm{P}<$ 0.05) than all additives. The differences among additives levels and sources on NFE digestibility were not significant.

\section{Nutritive values}

The TDN of control was lower $(\mathrm{P}<0.05)$ than all additives. All additives at level 2.5\% increased $(\mathrm{P}<$ $0.05)$ TDN than other levels. The DCP of all additives increased $(\mathrm{P}<0.05)$ than control as shown in Table $(5)$. However, the best values of DCP were recorded at $2.5 \%$ of garlic and peppermint and $2 \%$ of cinnamon. 
Table (4): Effect of different additives with different levels on digestion coefficients of nutrients

\begin{tabular}{|c|c|c|c|}
\hline \multirow{2}{*}{ Items } & Garlic & Cinnamon & Peppermint \\
\hline & \multicolumn{3}{|c|}{ Dry matter digestibility } \\
\hline Control $(0 \%)^{1}$ & $64.15 \pm 0.57^{\mathrm{a}}$ & $64.15 \pm 0.57^{b}$ & $64.15 \pm 0.57^{b}$ \\
\hline $1.5 \%$ & $66.71 \pm 2.02^{\mathrm{a}}$ & $68.05 \pm 0.90^{\mathrm{a}}$ & $67.28 \pm 1.06^{\mathrm{ab}}$ \\
\hline $2.0 \%$ & $67.19 \pm 0.69^{\mathrm{a}}$ & $68.90 \pm 0.46^{\mathrm{a}}$ & $68.23 \pm 0.99^{\mathrm{a}}$ \\
\hline \multirow[t]{2}{*}{$2.5 \%$} & $67.24 \pm 1.02^{\mathrm{a}}$ & $68.12 \pm 1.04^{\mathrm{a}}$ & $68.46 \pm 1.33^{\mathrm{a}}$ \\
\hline & \multicolumn{3}{|c|}{ Organic matter digestibility } \\
\hline Control $(0 \%)^{1}$ & $68.44 \pm 0.21^{\mathrm{c}}$ & $68.44 \pm 0.21^{\mathrm{c}}$ & $68.44 \pm 0.21^{\mathrm{c}}$ \\
\hline $1.5 \%$ & $70.85 \pm 0.32^{b}$ & $70.89 \pm 0.24^{b}$ & $71.49 \pm 0.33^{b}$ \\
\hline $2.0 \%$ & $70.75 \pm 0.25^{\mathrm{b}}$ & $71.21 \pm 0.34^{\mathrm{b}}$ & $71.49 \pm 0.05^{b}$ \\
\hline \multirow[t]{2}{*}{$2.5 \%$} & $73.20 \pm 0.35^{\mathrm{Ba}}$ & $73.43 \pm 0.23^{\mathrm{ABa}}$ & $74.34 \pm 0.17^{\mathrm{Aa}}$ \\
\hline & \multicolumn{3}{|c|}{ Crude protein digestibility } \\
\hline Control $(0 \%)^{1}$ & $54.36 \pm 0.15^{\mathrm{d}}$ & $54.36 \pm 0.15^{\mathrm{c}}$ & $54.36 \pm 0.15^{\mathrm{c}}$ \\
\hline $1.5 \%$ & $60.83 \pm 0.84^{\mathrm{Bc}}$ & $60.37 \pm 0.52^{\mathrm{Bb}}$ & $62.79 \pm 0.30^{\mathrm{Ab}}$ \\
\hline $2.0 \%$ & $59.79 \pm 0.05^{\mathrm{Cb}}$ & $63.38 \pm 0.70^{\mathrm{Aa}}$ & $61.28 \pm 0.14^{\mathrm{Bab}}$ \\
\hline \multirow[t]{2}{*}{$2.5 \%$} & $62.03 \pm 0.21^{\mathrm{Ba}}$ & $62.47 \pm 0.27^{\mathrm{ABa}}$ & $64.49 \pm 0.10^{\mathrm{Aa}}$ \\
\hline & \multicolumn{3}{|c|}{ Crude fiber digestibility } \\
\hline Control $(0 \%)^{1}$ & $54.14 \pm 0.38^{\mathrm{c}}$ & $54.14 \pm 0.38^{b}$ & $54.14 \pm 0.38^{c}$ \\
\hline $1.5 \%$ & $62.10 \pm 0.42^{\mathrm{Aa}}$ & $60.41 \pm 0.25^{\mathrm{ABa}}$ & $59.74 \pm 0.20^{\mathrm{Ba}}$ \\
\hline $2.0 \%$ & $56.01 \pm 0.20^{\mathrm{Bb}}$ & $59.92 \pm 0.50^{\mathrm{Aa}}$ & $59.51 \pm 0.14^{\mathrm{Ba}}$ \\
\hline \multirow[t]{2}{*}{$2.5 \%$} & $62.72 \pm 0.80^{\mathrm{Ba}}$ & $58.85 \pm 0.85^{\text {Аa }}$ & $55.51 \pm 0.46^{\mathrm{Ab}}$ \\
\hline & \multicolumn{3}{|c|}{ Ether extract digestibility } \\
\hline Control $(0 \%)^{1}$ & $49.43 \pm 0.21^{b}$ & $49.43 \pm 0.21^{\mathrm{c}}$ & $49.43 \pm 0.21^{\mathrm{c}}$ \\
\hline $1.5 \%$ & $48.87 \pm 0.27^{\mathrm{Ab}}$ & $48.42 \pm \mathrm{d} 0.13^{\mathrm{AB}}$ & $47.59 \pm 0.45^{\mathrm{Bd}}$ \\
\hline $2.0 \%$ & $51.67 \pm 0.36^{\mathrm{Ba}}$ & $53.71 \pm 0.05^{\mathrm{Ab}}$ & $51.67 \pm 0.06^{\mathrm{Bb}}$ \\
\hline \multirow[t]{2}{*}{$2.5 \%$} & $52.13 \pm 0.01^{\mathrm{Ba}}$ & $54.68 \pm 0.10^{\mathrm{Aa}}$ & $54.54 \pm 0.78^{\mathrm{Aa}}$ \\
\hline & \multicolumn{3}{|c|}{ Nitrogen free extract digestibility } \\
\hline Control $(0 \%)^{1}$ & $73.70 \pm 0.24^{b}$ & $73.70 \pm 0.24^{b}$ & $73.70 \pm 0.24^{c}$ \\
\hline $1.5 \%$ & $76.32 \pm 0.19^{\mathrm{a}}$ & $77.45 \pm 0.69^{\mathrm{a}}$ & $76.35 \pm 0.12^{b}$ \\
\hline $2.0 \%$ & $76.22 \pm 0.57^{\mathrm{a}}$ & $76.54 \pm 0.29^{\mathrm{a}}$ & $76.81 \pm 0.27^{a b}$ \\
\hline $2.5 \%$ & $76.81 \pm 0.33^{\mathrm{a}}$ & $76.86 \pm 0.59^{\mathrm{a}}$ & $77.67 \pm 0.44^{\mathrm{a}}$ \\
\hline
\end{tabular}

Control: Concentrate feed mixture and rice straw (2:1) without Additives.

${ }_{\mathrm{AB}}$ means in the same row with different superscripts differ significantly $(\mathrm{P}<0.05)$

${ }^{a b c}$ means in the same column with different superscripts differ significantly $(\mathrm{P}<0.05)$.

Table (5): Effect of different additives with different levels on total digestible nutrients (TDN) and digestible crude protein $(\mathrm{DCP})$

\begin{tabular}{|c|c|c|c|}
\hline \multirow{2}{*}{ Items } & Garlic & Cinnamon & Peppermint \\
\hline & \multicolumn{3}{|c|}{ TDN } \\
\hline Control (0\%) & $63.34 \pm{ }^{\mathrm{d}} 0.18$ & $63.34 \pm{ }^{c} 0.18$ & $63.34 \pm{ }^{\mathrm{d}} 0.18$ \\
\hline $1.5 \%$ & $65.91 \pm{ }^{\mathrm{Ab}} 0.08$ & $65.64 \pm{ }^{\mathrm{Ab}} 0.01$ & $65.18 \pm{ }^{\mathrm{Bc}} 0.02$ \\
\hline $2 \%$ & $64.83 \pm{ }^{\mathrm{Bc}} 0.46$ & $66.44 \pm{ }^{\mathrm{Ab}} 0.19$ & $65.81 \pm{ }^{\mathrm{ABb}} 0.09$ \\
\hline \multirow[t]{2}{*}{$2.5 \%$} & $67.22 \pm{ }^{\mathrm{ABa}} 0.25$ & $68.14 \pm{ }^{\mathrm{Aa}} 0.33$ & $66.84 \pm{ }^{\mathrm{ABa}} 0.04$ \\
\hline & \multicolumn{3}{|c|}{ DCP } \\
\hline Control (0\%) & $7.20 \pm{ }^{\mathrm{d}} 0.09$ & $7.20 \pm{ }^{b} 0.09$ & $7.20 \pm{ }^{b} 0.09$ \\
\hline $1.5 \%$ & $7.79 \pm{ }^{\mathrm{Bc}} 0.08$ & $8.14 \pm{ }^{\mathrm{Aa}} \mathrm{b} 0.13$ & $8.62 \pm{ }^{\mathrm{Aa}} 0.14$ \\
\hline $2.0 \%$ & $8.19 \pm{ }^{\mathrm{Bb}} 0.09$ & $8.53 \pm{ }^{\mathrm{Aa}} 0.05$ & $8.45 \pm{ }^{\mathrm{Ba}} 0.04$ \\
\hline $2.5 \%$ & $8.51 \pm{ }^{\mathrm{ABa}} 0.03$ & $8.38 \pm{ }^{\mathrm{Ba}} 0.03$ & $8.92 \pm{ }^{\mathrm{Aa}} 0.13$ \\
\hline
\end{tabular}




\section{REFERENCES}

Al-Hadeethi, A., M. D. Günal, A. Reyes and A. Abu Ghazaleh (2016). The effects of plants extracts on fermentation and methane production under in vitro conditions Glubal. J. Bio Sci. Biotec., 5(2): 253-260.

Ando, S., T. Nishida, M. Ishida, K. Hosoda and E. Bayaru (2003). Effect of peppermint feeding on the digestibility, ruminal fermentation and protozoa. Livest. Prod. Sci., 82: 245-248.

AOAC, Association of Official Analytical Chemists (1985). Official Methods of Analysis, $14^{\text {th }}$ ED. Washington, D.C., USA.

Benchaar, C., A. V. Chaves, G. R. Fraser, Y. Wang, K. A. Beauchemin and T. A. McAllister (2007). Effects of essential oils and their components on in vitro rumen microbial fermentation. Can J. Anim. Sci., 87: 413-419.

Benchaar, C. and H. Greathead (2011). Essential oils and opportunities to mitigate enteric methane emissions from ruminants. Anim. Feed Sci. Technol., 166: 338-355.

Cobellis, G., M. Trabalza-Marinucci and Z. Yu (2016). Critical evaluation of essential oils as rumen modifiers in ruminant nutrition: a review. Sci. Total Environ., 545: 556-568.

Duncan, D. B. (1955). Multiple range and multiple Ftest. Biometerics, 11: 1- 42.

Hosoda, K., T. Nishida, W. Y. Park and B. Eruden (2005). Influence of menthaxpiperita L. (peppermint) supplementation on nutrient digestibility and energy metabolism in lactating dairy cows. Asian-Aust J. Anim Sci., 18(12): 1721- 1726 .

IPCC (Inter govermental Panel on Climate Change) (2007). IPCC Fourth Assessment Report.

Johnson, K. A., and D. E. Johnson (1995). Methane emissions from cattle. J. Anim. Sci., 73: 24832492.

Kamra, D. N., N. Agarwal and L. C. Chaudhary (2006). Inhibition of ruminal methanogenesis by tropical plants containing secondary compounds International Congress Series, 1293: 156-163.

Khalesizadeh, A., A. Vakili, M. D. Mesgaran and R. Valizadeh (2011). The effects of garlic oil (Allium sativa), turmeric powder (Curcuma longalinn) and monensin on total apparent digestibility of nutrients in baloochi lambs. World Academy of Science, Engineering and Technol., 5: 11-27
Kongmun, P., M. Wanapat, P. Pakdee and C. Navanukraw (2010). Effect of coconut oil and garlic powder on in vitro fermentation using gas production technique Livestock Sci., 127: 38-44.

Macheboeuf, D., D. P. Morgavi, Y. Papon, J. L. Mousset and M. ArturoSchaan (2008). Doseresponse effects of essential oils on in vitro fermentation activity of the rumen microbial population. Anim. Feed Sci. Technol., 145: 335350.

McDougall, E. I. (1948). Studies on ruminant saliva. 1. The composition and output of sheep's saliva. Biochem. J., 43: 99-109.

Mitsumori, M. and W. Sun (2008). Control of rumen microbial fermentation for mitigating methane emissions from the rumen. Asian-Aust. J. Anim. Sci., 21(1): 144-154

Ozkan, C. O., A. Kamalak, A. I. Atalay, A. Tatliyer and E. Kaya (2015). Effect of peppermint (Menthapiperita) essential oil on rumen microbial fermentation of barley grain. J. Appl. Anim. Res., 43(3): 287-290.

Patra, A. K. and Z. Yu (2012). Effects of essential oils on methane production and fermentation by, and abundance and diversity of, rumen microbial populations. Appl. Environ. Microb., 78: 42714280.

Sallam S. M. A., S. A. M. Abdelgaleil, I. C. S. Bueno, M. E. A. Nasser, R. C. Araujo and A. L. Abdalla (2011). Effect of essential oils on ruminal fermentation, microbial population and methane emission in vitro. Options Méditerranéennes: Série A. Séminaires Méditerranéens, 99: 149156.

Takahashi, J., B. Mwenya, B. Santoso, C. Sar, K. Umetsu, T. Kishimoto, K. Nishizaki, K. Kimura and O. Hamamoto (2005). Mitigation of methane emission and energy recycling in animal agricultural systems. Asian-Aust. J. Anim Sci., 18: 1199-1208.

Tilley, J. M. A and R. A Terry (1963). A two-stage technique for the in vitro digestion of forage crops Current Contents/J. British Grassland Society, 18: 104-111.

Van Keulen, J. and B. A. Young (1977). Evaluation of acid-insoluble ash as a natural marker in ruminant digestibility studies. J. Anim. sci., 44(2): $282-287$. 


\section{دراسات غذائية علي استخدام بعض النباتات الطبيعية في تغذية الأغنام و أثر ذلك علي إنتاج الغاز والهضم}

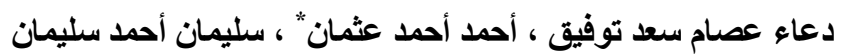

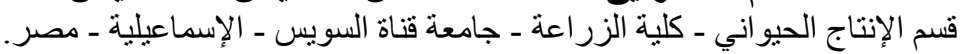

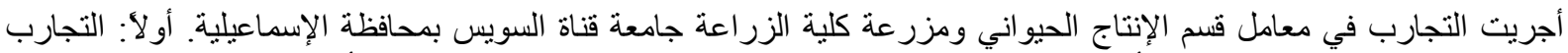

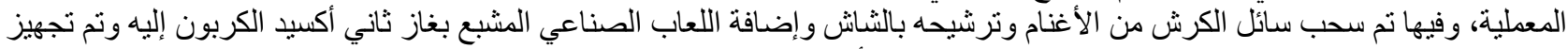

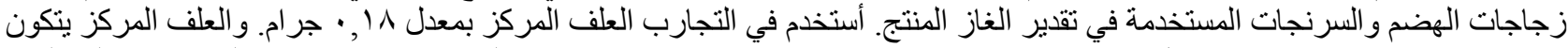

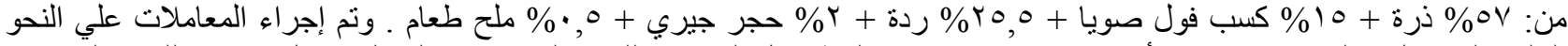

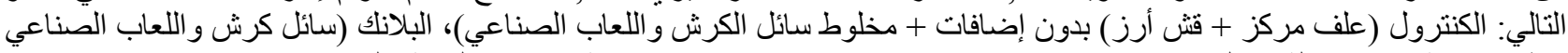

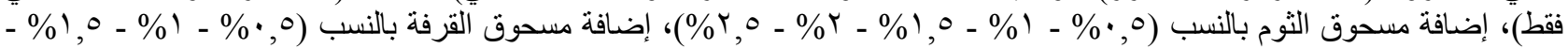

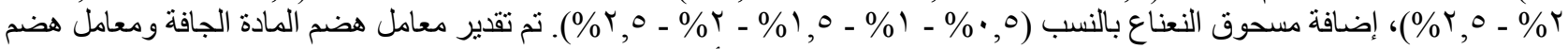

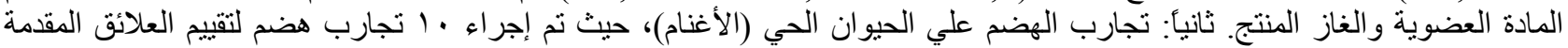

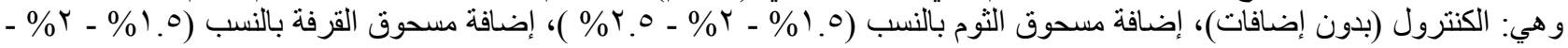

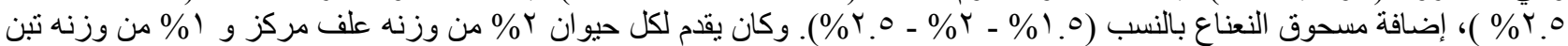

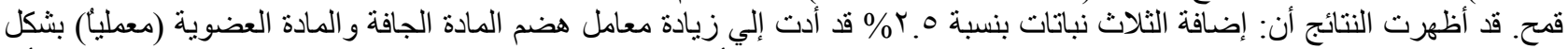

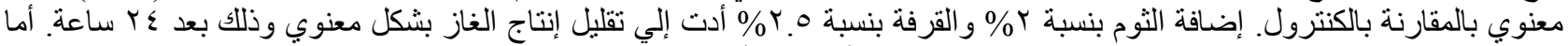

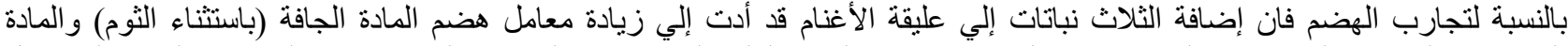

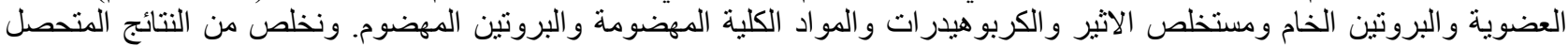
عليها أنه يمكنتا أن نوصي (تحت نفس ظروف النئ التجربة) بإضافة الثوم والقرفة والنعناع إلي علائق الأغنام من اجل تقليل إنتاج غاز الميثان وتحسين الهضم و أداء الحيوان بشكل عام. 